\title{
STUDY OF THEAPPLICATION OF ENERGY GENERATION SYSTEMS WITH MINI HYDROELECTRIC
}

\section{ESTUDIO DE LA APLICACIÓN DE SISTEMAS DE GENERACIÓN DE ENERGÍA CON MINI HIDROELÉCTRICAS}

\author{
Jhan Piero Rojas Suarez ${ }^{1}$ \\ Mawency Vergel Ortega² \\ *Sofia Orjuela Abril ${ }^{3}$ \\ Universidad Francisco de Paula Santander, \\ Cúcuta, Colombia
}

\section{RESUMEN}

Año tras año, los estudios medioambientales muestran un crecimiento exponencial de las emisiones de gases de efecto invernadero procedentes de las centrales termoeléctricas y generadores que utilizan combustibles fósiles $1 \quad$ Facultad de Ingenierías, Universidad Francisco de Paula Santander, Cúcuta, Colombia. Correo jhanpierorojas@ufps.edu.co ORCID iD: https://orcid.org/0000-00032682-9880

2 Departamento de Matemáticas y Estadística, Universidad Francisco de Paula Santander, Norte de Santander, Cúcuta, Colombia, correo: mawencyvergel@ufps.edu.co Orcid: https://orcid.org/0000-0001-8285-2968

3 Facultad de Ciencias Empresariales, Universidad Francisco de Paula Santander, Cúcuta, Colombia. Correo: sofiaorjuela@ufps.edu.co ORCID: https://orcid.org/00000002-9742-8673 como el carbón, el petróleo y el gas natural, entre otros. Esto resalta la importancia de un llamado urgente a los países para desarrollar al máximo la implementación de energías limpias y renovables. Siendo Colombia, el 4to país en el mundo en tener una amplia capacidad hidráulica, es uno de los más pobres en la implementación de regulaciones e incentivos, por parte de las entidades gubernamentales, para el uso de este recurso en la generación de energía renovable, gobiernos como el de China, han entendido la ventaja que implica el uso de estas alternativas energéticas, siendo pioneros en la implementación de pequeñas plantas en zonas rurales donde el acceso a las redes eléctricas es difícil. El desarrollo de este tipo de generadores abre un abanico de oportunidades 
para Colombia, pero la más interesante es la posibilidad de diversificar la matriz energética y la ventaja de poder llegar a pequeñas comunidades y pueblos que no cuentan con este beneficio, como es la energía eléctrica. En este punto, es clave la implementación de las minicentrales eléctricas, que son perfectas para estas necesidades.

PALABRAS CLAVE: Matriz energética, gases de efecto invernadero, centrales hidroeléctricas, políticas, energías renovables.

\section{ABSTRACT}

Year after year, environmental studies show exponential growth in greenhouse gas emissions from thermos-electric plants and generators that use fossil fuels such as coal, oil, and natural gas, among others. This highlights the importance of an urgent calling to countries for developing to the maximum the implementation of clean and renewable energy. Being Colombia, the 4th country in the world to have a wide hydraulic capacity, it is one of the poorest in the implementation of regulations and incentives, by government entities, for the use of this resource in the generation of renewable energy, governments like China, they have understood the advantage that the use of these energy alternatives implies, being pioneers in the implementation of small plants in rural areas where access to electricity grids is difficult. The development of this type of generators opens up a range of opportunities for Colombia, but the most interesting is the possibility of diversifying the energy matrix and the advantage of being able to reach small communities and towns that do not have this benefit, such as electrical energy. At this point, the implementation of the mini-micro power stations is key, which is perfect for meeting these needs.

KEYWORDS: Energy matrix, greenhouse gas, hydroelectric plants, policies, renewable energy.

\section{INTRODUCTION}

In recent years, there has been a progressive growth in the demand for energy at the national and international levels. Parallel to this, it can be noted a significant increase in the greenhouse gas generation, as can be seen in Figure 1 (XM, 2020). The huge importance gained from the exploration and the application of renewable energies would explain such an increase. When renewable energies are named it refers to those based on the use of natural resources, namely wind, water, sun or biomass; its use is aimed to avoid and reduce the use of fossil fuels, which is one of the main factors for generating the largest amount of pollutants worldwide. On the other hand, fossil fuels are finite resources, something that does not represent a concern for renewable energies, because natural resources are able to unlimited self-restored themselves.

One of the main means to generate energy through natural resources is using hydroelectric plants. The beginning of hydroelectric can be reached out even before Christ. Although there is not an exact date, there are remains, such as designs and papers, where it was explained the use of hydraulic wheels implemented to produce commercial energy. These sorts of devices were mainly introduced by the ancient Romans and Greeks. These wheels were moved with the help of water flow and were used mostly to grind wheat and make flour (Kumar y Schei, 2011). 
Figure 1: Greenhouse gas emissions (in tons). Source of data: Prepared by the authors based on information from $(\mathrm{XM}, 2020)$.

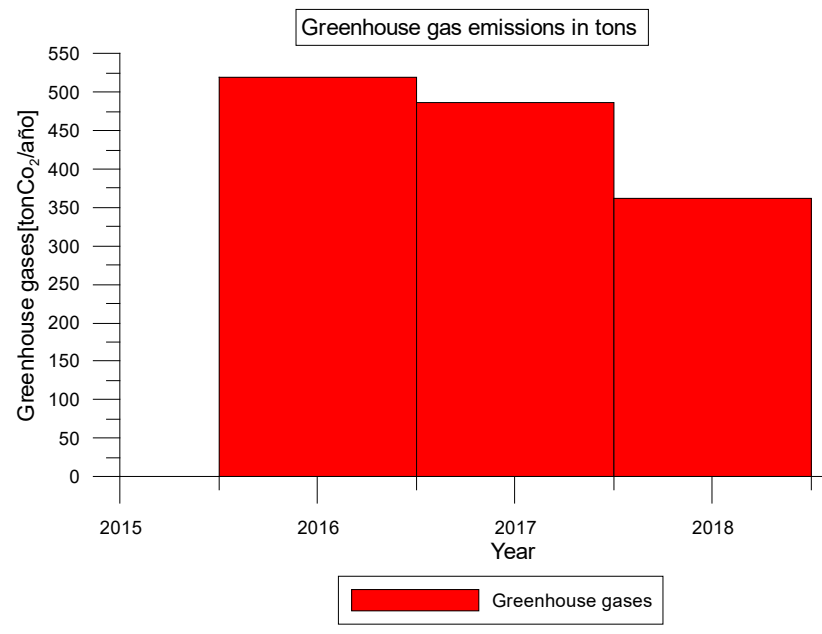

During the Middle Ages, the hydraulic wheels were able to develop a power up to 50 horsepower. Later, they were of great importance during the Industrial Revolution, here their implementation in the textile industry was vital, because, even though the steam engine was already running up, its source of power, coal, was quite scarce. Hydropower was a great boost for the industrial cities that were rising in Europe and America. Through the 19th Century took place the creation of the first hydroelectric power stations. One of them dates to 1870 , in Cragside, Rothbury, England. Now, the industrial use of energy occurred in 1880 in Grand Rapids, Michigan, and it was employed to illuminate the theaters. Then, in 1881, a dynamo-type electric generator, connected to a turbine from a mill, provided street lighting at Niagara Falls in New York, from there, the history carries on, until it reaches the large power plants that are wellknown these days.

The generation of energy in hydroelectric plants depends on the fall or the height of the water and its volume. The water came from the rivers, provides two types of energy: the kinetic one, which is created by the speed of the flowing stream. The other one is the potential one, and this one can be obtained based on the height from which the water will be falling down. It passes through a turbine, which transmits the energy received by the water to a generator where it is transformed into electrical energy (Vineet, Neha y Deepti, 2015).

In 2010 the hydroelectric plants produced around $16 \%$ of the electricity worldwide, and their installed capacity was $1010 \mathrm{GW}$ by the end of the same year. These results turn them into one of the most relevant renewable energy sources in the electricity production field. Asia happens to be the continent with the greatest SHPP installed in the entire world, with more than $40 \mathrm{GW}$. Europa is located in second place with a $13 \mathrm{GW}$, and in the third place, we can find America (North, Center and South Renewables, 2010).

\section{METHOD}

The Colombian Hydroelectric System has a lot of important advantages regarding the electric energy supply, thanks to its strength. Nevertheless, it presents a huge failure when ensuring full coverage and quality to those areas with difficult access. In order to fully meet the energy needs in these areas, they utilize fossil fuels, which provide a service quite poor and inconsistent. Besides this, they are very pollutant and expensive (Morales, Corredor, Paba y Pacheco, 2014). Hydroelectric plants are a perfect alternative for Colombia, thanks to their topography, rainfall, and water resources. However, these are not enough to fulfill the energy demand and get to every corner of the country. That is the reason why it is necessary to diversify the energy matrix, developing alternatives such as mini-micro hydroelectric power plants, these as their name say, are small-scale hydropower plants taken from large power plant designs. Even when both share the same operating principle, they have differences between each other, resulting in, as mentioned 
above, diversification in the country's energy matrix, a subject that we will delve into later.

Although it does exist this variety, the use of this type of generators in the country is minimum. In fact, it does not exceed 3\%, approximately (Gallego, 2015). Their high operating and preoperating costs make them a not so viable option within the industrial field. Considering this reality, it is essential that the government designs a whole set of policies to promote its production and implementation. These policies should be aimed to incentive the use of these generators in small and big companies, reflecting benefits for both parties.

\section{RESULTS AND DISCUSSION}

\section{National context}

According to the World Bank, Colombia is the fourth country in the world with the largest hydraulic capacity. It has an average flow of $66440 \mathrm{~m}^{3} / \mathrm{s}$, this equivalent in terms of the annual volume of $2113 \mathrm{~km} 3$, in a total area of 1141748 km² (Vargas, Alarcón y Fajardo, 2011). XM, an ISA company, specialized in real-time system management, reported that back in March 2014, the hydropower used in Colombia was $69.9 \%$. They also estimated that between 2012 and 2018, there would be an increase of $3419 \mathrm{MW}$ (XM S.A, 2014).

Small hydroelectric power plants are a great option for expanding supplies for all the interconnected regions of the country, where exists a connection to electricity grids and for those regions with difficult access. $\quad T h$ e National Energy Plan (PEN) in 2010, established that small hydroelectric plants could benefit from the 720000 basins and micro basins, apart from 1,600 bodies of water, such as lagoons, lakes, and reservoirs, which have an approximate volume of $26300000 \mathrm{~m}^{3}$, and approximately reserves of 140879 groundwater (Gallego, 2015).
Taking into account the environmental problems that currently impact the country, and the growing energy demand, government entities have implemented stimulation in the development and application of renewable energy methodologies. Nevertheless, there is no strong regulation to encourage their use. In spite of this, a progressive analysis of the laws and regulations on the use of renewable energy, like the one that read below, allows us to observe that even though, it is a fact that our country has great potential water to explore, there is also a lack of policies to encourage its implementation, diminishing the strengthening of the national electricity grid.

\section{POLICIES FOR THE IMPLEMENTATION OF RENEWABLE ENERGY IN COLOMBIA.}

Even though there are still no incentives and regulations that allow a major development in the implementation of small hydroelectric plants in the country, can make a chronological review of the policies that are related to the implementation of these renewable energy generators, they are:

$\checkmark \quad$ Law 1 of 1984 , It was stated that studies in the development of alternative energy sources should be supported and their use evaluated as part of the strengthening of the national energy matrix. (Congreso de la Republica de Colombia, 1984).

$\checkmark \quad$ Decree 2119, December 29, 1992, the Ministry of Mines and Energy, the Institute of Nuclear and Mineral Affairs of Colombia, are restructured. (Ministerio de Minas y Energía, 1992)

$\checkmark \quad$ In 1992, the National Energy Commission was transformed into the UPME Energy Mining Planning Unit, in charge of planning energy mining development, managing sector public policy, in coordination with other related actors. (UPME, 2014). 
$\checkmark \quad$ Law 143 of 1994 , established "the regime for the generation, interconnection, transmission, distribution, and commercialization of electricity in the national territory, authorizations are granted, and other provisions are issued in the energy field" (Congreso de la Republica de Colombia, 1994).

$\checkmark \quad$ Laws 142 and 143 of 1994, promote skills in generation and marketing activities and start the wholesale market, which is regulated by CREG, through the Network Code, which is the current regulation that governs the National Interconnected System. (Carvajal \& Marín, 2013).

$\checkmark \quad$ Law 697, Regulatory Decree 3683, December 19, 2003, The rational and efficient use of energy is promoted, in the same way, the implementation of alternative energies. (Congreso de la Republica de Colombia, 2008).

$\checkmark \quad$ Decree 2501, July 2007, establishes the rational and efficient use of electrical energy. (Ministerio de Minas y Energía, 2007).

$\checkmark \quad$ Resolution 181401, October 2004, the greenhouse gas emission factor is adopted for energy generation projects with renewable sources connected to the National Interconnected System whose installed capacity is equal to or less than $15 \mathrm{MW}$ (Ministerio de Minas y Energía, 2004).

The above is part of the legislative instrument that Colombia has, with respect to sustainable development and the implementation of renewable energies, in a search to diversify the energy matrix and, in the same way, contribute to the improvement and preservation of the environment for future generations.

\section{DIVERSITY IN THE ENERGY MATRIX, ALTERNATIVES}

Large hydroelectric power plants are an interesting option for Colombia, as was previously mentioned. Unfortunately, they seem to be not enough to fully supply energy to the entire country, and this scenario is common worldwide. That is why, in many countries of the world, including Colombia, are granting the means to implement small hydroelectric power plants, PCHS, specifically Micro-Mini power plants. These devices generated power can be classified in Colombia, as less than 0.1 MW in the case of micro power plants, and between 0.1 to $1 \mathrm{MW}$ for mini power plants (Vargas et al.,2011). It is important to remark, that there is not a classification under power or generation parameters worldwide adapted, because these categories are defined according to the legal regulations that each govern has. This explains the fact that the technological and application characteristics vary for each country, even within the same country, these settings may vary from one area to another.

\section{THE MINI-MICRO HYDROELECTRIC PLANTS.}

Micro-mini centrals can be used in all cases where an electrical supply is needed, and there is the availability of a water source, even if it is low in volume, and with few meters high. Those tough conditions make them ideal for places with difficult access to electricity grids, for instance, mountainous areas, geographically isolated from large cities, townships, town, and others. In most of the places, they are economically attractive, in the case of Colombia, they are a good option for places where electricity transmission costs are very high and where diesel generators are usually used, with high maintenance costs and low efficiency to supply the energy demand in these areas.

hese types of generators are capable of producing a continuous supply of electrical energy almost without interruption. Compared to other renewable technologies, which makes them an alternative for developing countries, thanks to the fact that their size makes manufacturing and its subsequent maintenance low cost compared 
to large power plants. Another key point is that it is not necessary the presence of staff all the time, thanks to the fact that at present we can make use of systems with remote control, and it will only be necessary for an operator who periodically controls the correct operation of the hydraulic installations (Reyna, Lábaque, Reyna, Riha y Irazusta, 2017).

Its operating principle does not vary with respect to large hydroelectric plants, just as large hydroelectric obtain their energy by taking advantage of the potential energy of a body of water and later transforming it into mechanical energy once it passes through the hydraulic turbine, which drives the generator that turns mechanical energy into electrical, its size is not a problem so that they are as efficient as large power plants. like the large hydroelectric plants, we can classify them according to their operation, in relation to the way in which they collect and accumulate the water, they can be: Run-and-river system, this system is based on diverting through a channeled a part of the river and take it to the place where the energy transformation process will take place and once this procedure is completed the water returns to the river to follow its natural course. We also find: Regulated flow plants (dams), is a system that allows greater control of the flow of the water that will be processed through the construction of a water reserve, also known as a reservoir. This variation in the way in which the water resource is captured makes the implementation of these small plants greatly increase, because they can be adapted to different environments, creating greater diversification of the energy matrix (Gallego, 2015).It is important to highlight again that the efficiency of hydroelectric plants does not change due to their size (Large, mini, micro), their general and operating properties are similar, the results and even the characteristics of hydroelectric plants, turbines, generators, reservoirs, and other elements are representative of each project, and even depending on the place where it will be implemented, in the same way as the flow of the water source, the waterfall, among other factors. On the other hand, there are differences in the environmental, scope, economic, and other levels, as will be appreciated later.

\section{MINI-MICRO HYDROELECTRIC POWER PLANTS IN COLOMBIA}

Currently, Colombia has 23 active hydroelectric plants, which make a significant contribution to the interconnected national system, producing a total of $16990.39 \mathrm{GWh}$ of useful capacity and a percentage of $33.93 \%$ of useful daily volume, that is, $5765.66 \mathrm{GWh}$ of daily useful power. In Figure 2, they show us detailed information by region with their respective water contributions (XM, 2020).

Figure 2: Hydroelectric power generation in Colombia (in GWh). Source of data: Prepared by the authors based on data from (IEA, 2019)

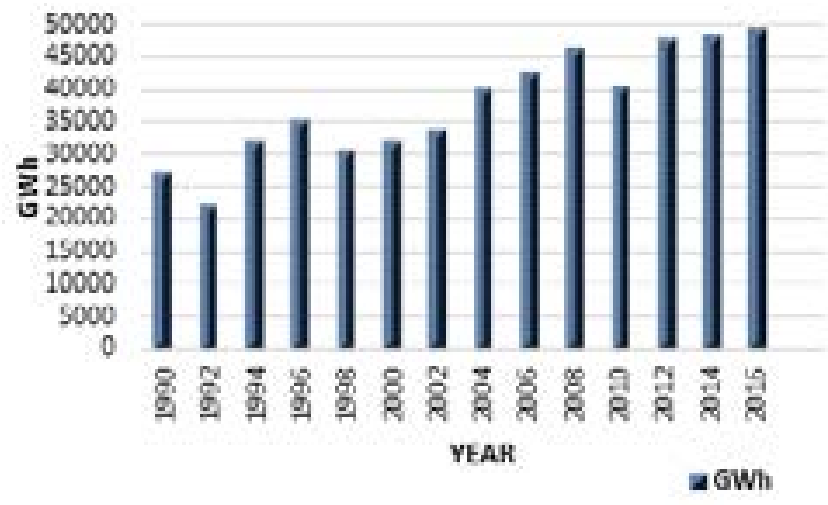

As previously mentioned, Colombia is the fourth country in the world with the greatest hydraulic capacity, and currently, only a small percentage of that water potential is used. Besides that, currently, in Colombia, there are 115 small hydroelectric power plants operating in the country, which include mini-micro power plants with an effective capacity of $867.31 \mathrm{MW}$, among which some of them stand out for greater capacity such as Hydro Montañitas in Antioquia, Tunjita in the department of Boyacá, but not all of them 
take part in the energy market such as Aures Bajos, which is one of the most recent and is also found in Antioquia, Rio Mayo in Nariño, and Charquito in the department of Cundinamarca (Paratec, 2020)(XM, 2020)(UPME,2020).

It would be of great advantage for the country if all or most of the small power plants were taken into account, and if the water capacity that Colombia possesses could be used by generators such as these, the negative environmental impact in the country would be highly reduced. In addition, it would take energy to remote parts of the country that do not have this service yet (Fig. 3).

Figure 3: Hydraulic contributions in each of the regions of Colombia (in GWh). Source of data: Prepared by the authors based on information from (XM, 2020).

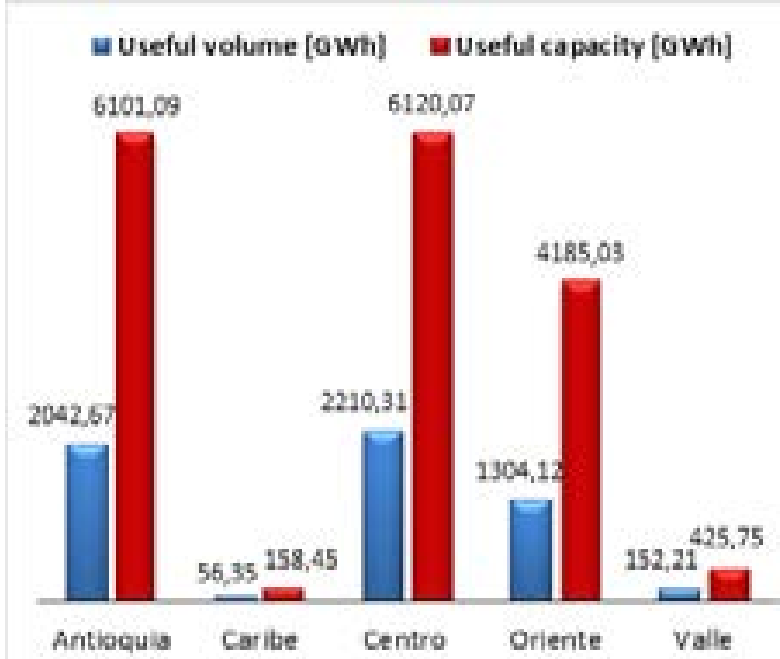

\subsection{INTERNATIONAL CONTEXT}

The worldwide energy generation is mostly based on the use of fossil fuels, such as oil, coal, and gas. Currently, researchers and governments are looking for different options to cover energy needs, because, with the pass of the time, the negative aspects will be bigger than the benefits provided by this type of fuel. Some of the most relevant and common reasons in the international ambit are the following: fossil fuels are limited resources, they are not fully accessible due to the fact that they are only found at specific points on the planet, it should also be noted that they are high pollutants. Currently, the reserve of these fuels is running out, which generates uncertainty and increases the need to use other energy generation alternatives. In Fig. 4 is observed how is the generation of electrical energy with hydroelectric power worldwide. At the global level, the implementation of small hydroelectric plants has been driven by sustainable generation policies, given the global increase in greenhouse gas emissions and their detrimental effects on humanity, and, like Colombia, for promoting diversification in the energy matrix. Hydroelectric energy occupies around $20 \%$ of the energy generated worldwide. It is important to mention that the exploration and implementation of energy through water sources are in a more mature stage compared to the use of other renewable energy sources.

Figure 4: The amount of hydroelectric power generation in the world, during the years (in GWh). Source of data: Prepared by the authors based on data from (IEA, 2019)

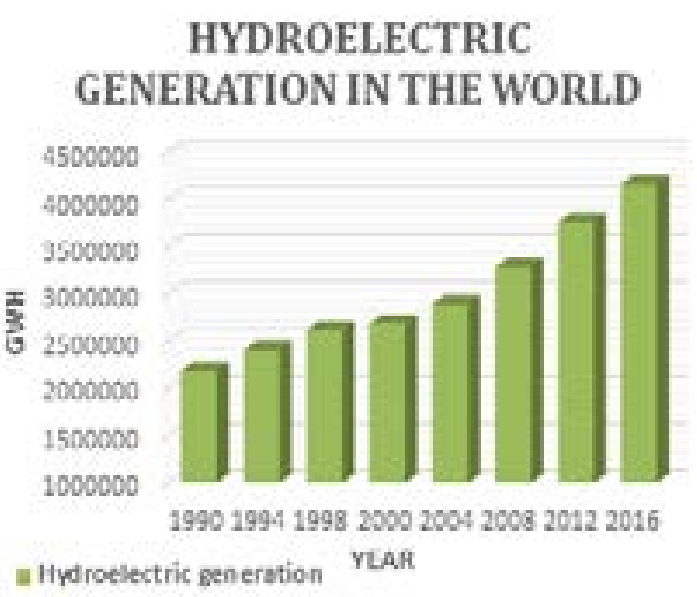

This generation system is used in approximately 150 countries, with China ranking first, followed by Japan and the United States, and countries such as Germany, Brazil, Spain, and India, which have the largest number of small power plants in use (Gallego, 2015). 


\section{CHINA}

As mentioned above, China is the country that has the largest development in small hydroelectric plants around the world, being classified as plants that have the capacity to generate up to $50 \mathrm{MW}$, currently, its greatest use is in rural areas of the country. In mountain areas, they are not interconnected due to their difficult access (Gallego, 2015).

Thanks to its technical and economic potential, it is one of the first countries in the world to implement this energy generation technique, being a guide for other countries due to its extensive experience, with a power of $128 \mathrm{GW}$, the capacity of $65.68 \mathrm{GW}$, reported in 2012 and an annual production that exceeds 217300 GWh (Gallego, 2015). It has a growth rate of approximately $20 \mathrm{GW}$ per year, which indicates that investment in small hydroelectric plants, to supply energy demand in China, has a positive outlook for development (Figure 5).

Figure 5: Hydroelectric power generation in China (in GWh). Source of data: Prepared by the authors based on data from (IEA, 2019)

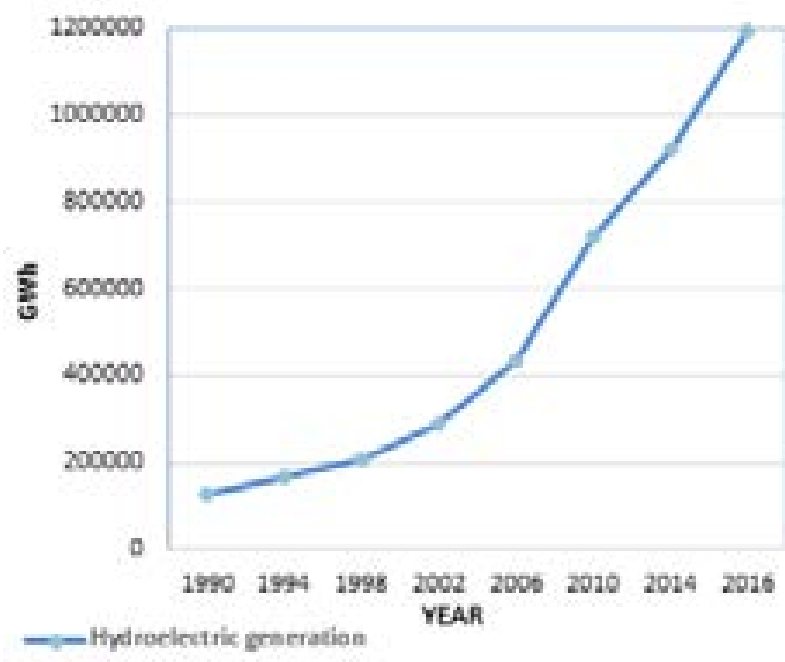

INDIA

It is estimated that $84000 \mathrm{MW}$ is the exploitable hydraulic power in India, and $6780 \mathrm{MW}$, evaluated for small plants. Furthermore, 56 places have been found for pumped storage schemes, with an installed capacity of approximately 94000 MW. The installed capacity for September 2013 was approximately $39788.40 \mathrm{MW}$, which is $17.39 \%$ of the total energy generated in India (Vineet et al., 2015).

\section{BRAZIL}

With respect to LatinAmerica, Brazil is the country that is positioned with the greatest development and implementation of small hydroelectric plants, and it has an installed capacity of approximately $2 \mathrm{GW}$ and a potential of $9.5 \mathrm{GW}$, this advance in the use of resources Renewable, is due to the economic incentives that the government has proposed with the help of the National Development Bank already programmed that have attractive financial environments for the generating entities (Gallego, 2015).

\section{EUROPEAN UNION}

The White Paper for a Common Strategy and an Action Plan for Renewable Energies is the legislative framework governing the use of renewable energy in the European Union, developed in 1997 by the Commission of the European Communities, established an increase of $4500 \mathrm{MW}$, of installed power in mini centrals, which would mean an annual increase from $37 \mathrm{TWh}$ to $55 \mathrm{TWh}$. Within the countries that comprise the European Union, Spain is one of the countries that most applied to this type of energy. The annual water energy production in Spain depends on the availability of the hydraulic resource, in wet seasons it exceeds $40000 \mathrm{GWh}$, but in dry seasons it does not reach $25000 \mathrm{GWh}$, the average in the last ten years has been 32500 GWh (2006), which means $17 \%$ of the energy production of that country (Castro, 2006).

\section{JAPAN}

In September 2011, it had 1198 small hydroelectric plants with an approximate 
capacity of $3225 \mathrm{MW}$. These small hydroelectric plants represent $6.6 \%$ of Japan's total installed hydroelectric capacity. Japan has a projection for 2030 of generating $9.6 \%$ of its electricity through hydroelectric power.

\section{ADVANTAGES AND DISADVANTAGES OF MINI-MICRO HYDROELECTRIC POWER PLANTS}

As it has been previously affirmed, hydroelectric plants allow a positive contribution to the environment, since their activity generates lower levels of production of greenhouse gases, unlike energy produced with other types of fuel, at the energy level they are highly efficient and economically, its manufacturing costs are lower compared to other generating plants. However, there are several disadvantages with respect to large hydroelectric plants, and one of them lies in the way in which the water resource is captured, the vast majority of hydroelectric plants use the water collection system through reservoirs, also known as dams, which generate a negative environmental impact at the time of construction and during their operation, since this activity leads to the deforestation of a considerable number of hectares of forests and green areas, due to their large size, this implies a disturbance of wildlife, because animals must vacate their habitat as well as people living in these areas, which can lead to increased impoverishment of people(AE News, 2019).

Similarly, the construction of dams is the cause of eutrophication, a type of alteration of the body of water that is the cause of the formation of sediments and nutrients in stagnant water in the reservoir, which negatively affects aquatic fauna in the part of the river that is being used(Mongabay, 2018). For all the above, it is important to carry out previous studies of the place that were required to build this type of power plant and thus be able to avoid or do the least possible damage and obtain the maximum use of the resource. However, with mini-micro plants offers a different panorama, not only are they beneficial in creating a range of energy options, but also their environmental advantages are more attractive than those of large plants, for example, most of the small hydroelectric plants use the run-and-river system, to capture the water resource, which is a friendly method with the aquatic ecosystem, because the stretch of water used in power generation returns to the main flow with a very low impact on the environment local, in the same way, it reduces the danger to the decrease in the levels of the rivers because this system allows them to remain constant.

Another advantage is that they can operate with low flow rates and small jumps without affecting their efficiency, which generates reliability, since they are capable of producing a continuous supply of electrical energy, even in times of low rain. In terms of costs, they are excellent, thanks to the fact that they require few components for their construction, such as turbines, generator, and a regulation system. In terms of economy, they are much more profitable, and maintenance costs are relatively low. They are good for developing countries like Colombia due to their low prices and durability. They also have a great advantage over large power plants and are perfect for supplying electricity to rural areas or small communities and towns that do not have access to electricity grids and demand the necessity of it(Juan Gallego, 2015)(cecu, 2018).

Taking all this into account, it is attractive to take into account and start promoting the implementation of mini hydroelectric power plants to diversify our energy matrix, contribute to the conservation of the environment and supply the country's energy demand.

\section{CONCLUSIONS}

The Small Hydroelectric Power Plants (SHPP) present themselves as the ideal alternative to enhance the energetic supply system in the 
country, not only for the interconnected areas but also for those that are geographically isolated; places where an electric network installation is practically impossible to achieve. SHPPs constitute a real opportunity for Colombia to get its lack of coverage towards energy supply for its entire territory. SHPPs present important advantages such as they can be easily adapted in areas with difficult access, like highland regions. Economically speaking, they also provide a positive side, since their dimensions are smaller, it means that their manufacturing and maintenance processes are way less expensive than the large hydroelectric and fossil fuel generators power plants' ones.

SHPPs are daily gaining ground in Colombia, as a more beneficial electric generation alternative. Nevertheless, Colombia has not developed yet the legal means to drive the implementation of this sort of electric generators. Therefore, we strongly believe that it is vital to create and apply policies that will encourage and ensure the SHPPs implementation. Along with this, the government should reinforce the research field aiming to develop this type of technology, and eventually migrate the supply from fossil fuels to renewable sources.

It is valid to say that there has been a notorious interest from the government on SHPPs implementation. As proof, in the last year's new laws have been under study, and then approved supporting these type of energy generators. Although important improvements have been made, there is a long path to cover because the business sector finds that SHPP's implementation represents a hugely risky investment.

The big boom that small hydropower plants have had in countries like China, Japan, Germany, Brazil, Spain, and India, which represent the most significant economic systems in the whole world, has to do with the incentives (taxes and economic) and benefits offered by the local governments. These entities do recognize the SHPPs as a relevant source of development and improvement for those areas where energy supply is no constant.

\section{BIBLIOGRAPHIC REFERENCES}

Castro, A. (2006). Minicentrales hidroeléctricas. Manuales de energías renovables. (Pp. 5-175) Madrid, España.Available from: https://www.idae. es/uploads/documentos/documentos_2.1.7_ Minicentrales_hidroelectricas_125f6cd9.pdf

Confederación de consumidores y usuarios. Energía minihidráulica proyecto RES \& RUE dissemination. Available from: https:// cecu.es/campanas/medio\%20ambiente/ res\&rue/htm/dossier/4\%20minihidraulica. htm\#6. \%20Tr\% C3\%a1mites $\% 20$ para $\% 20$ la \%20realizaci\%C3\%b3n\%20de \%20un\%20 sistema\%20minihidr\%C3\%a1ulico

Congreso de la Republica de Colombia. (1984). Ley No. 01 de 1984. Available from: ftp://ftp. camara.gov.co/camara/basedoc/ley/1984/ ley_0001_1984.html

Congreso de la Republica de Colombia. (1994). Ley No. 143. Available from: http://www. alcaldiabogota.gov.co/sisjur/normas/Norma1. jsp?l=4631

Congreso de la Republica de Colombia. (2008, July 16). Ley No. 697.

Cuadros, H., Cuellar, Y., Chiriví, S., Guevara, M. (2019). GHG diffuse emissions estimation, and energy security to ENSO using MEERA-2 for largely hydroelectricity-based system. Revista facultad de ingeniería, 91, 70-82.

Gallego, J. (2015) Políticas para el aprovechamiento del potencial hidroenergético en Colombia mediante pequeñas centrales. Universidad Nacional de Colombia, Medellín, Colombia. 
Gil, M., Smith, R., Angel, W. (2004) Análisis de inversión en pequeñas centrales hidroeléctricas. Universidad Nacional de Colombia, Medellín, Colombia.

IEA. (2019). Hydroelectric electricity generation in Colombia. Data from: https://www.iea.org/ data-and-statistics?country= COLOMBIA\&fuel=Renewables $\% 20$ and $\%$ 20waste\&indicator $=$ Hydroelectric $\% 20$ electricity\%20generation

IEA. (2019). Hydroelectric electricity generation in Japan. Data from: https://www.iea.org/data -and-statistics?country=JAPAN\&fuel= Renewables\%20and\%20waste\&indicator= Hydroelectric\%20electricity\%20generation

IEA. (2019). Hydroelectric electricity generation in the World. Data from: https://www.iea.org/ data-and-statistics?country= WORLD\&fuel=Renewables\% 20and\%20waste\&indicator=Hydroelectric $\%$ 20 electricity $\% 20$ generation

Kumar, a., schei, t.(2011). Hydropower.

Renewable energy sources and climate change mitigation (Pp. 437-496)

Cambridge University Press. Available from:

https://www.ipcc.ch/site/assets/ uploads/2018/03/Chapter-5-Hydropower-1.pdf

Manotas, D. (2013). Evaluación de proyectos de generación eléctrica bajo incertidumbre en política climática. Entramado, 9(1), 102-117.

Marín, J., Carvajal, S., Guerrero, J. (2017).

Island operation capability in the

Colombian electrical market: a promising ancillary service of distributed energy resources. TecnoLógicas, 21(42), 169-185.

Ministerio de Minas y Energía. (1992, de Diciembre de). Decreto 2119 de 1992. Ministerio de Minas y Energía.
Ministerio de Minas y Energía. (2004, October 29). Resolución 181401.

Ministerio de Minas y Energía. (2007, July). Decreto 2501 de 2007

Moreles, S., Corredor, L., Paba, J., Pacheco, L. (2013). Stages in the development of a small hydropower project: Context and implementation basic criteria. Universidad Nacional de Colombia, Medellin, Colombia.

Moscoso, L., Montealegre, L. (2015). Propuesta de un modelo para evaluar impactos asociados al componente flora en proyectos de desarrollo. Producción + limpia, 10(2), 69-79.

MX. (2018). Cifras relevantes de 2018. Data from: http://informes.xm.com.co/gestion/2018/ generalidades-xm-2018/PublishingImages/ Paginas/cifras-relevantes-xm-2018/cifras.jpg

MX. (2020). Agentes del mercado. Available from: http://informesanuales.xm.com.co/2014/ sitepages/operacion/1-4-Agentes-del-mercado. aspx

MX. (2020). Descripción sistema hidrológico SIN. Available from: http://paratec. $\mathrm{xm} . c 0 m . c o / p a r a t e c / s i t e p a g e s / h i d r o l o g i a$. aspx?Q=descripcion

REN21. (2010). Renewables 2010 global status report. Available from: https://www.ren21.net/ wp-content/uploads/2019/05/GSR2010_FullReport_English.pdf

Reyna, T., Lábaque, M., Reyna, S., Riha, C., Irazusta, B. (2017) Energía mini y micro hidráulica: Aporte contra el cambio climático. Universidad Nacional De Córdoba, Córdoba, Argentina.

UPME. (2014). UPME

UPME. (2020) Balance energético colombiano. BECO. 
Vargas, F., Alarcón, A., \& Fajardo, C. (2011). Pequeñas y micro centrales hidroeléctricas: Alternativa real de generación eléctrica. Revista Informador Técnico, (75), 73-85.

Vineet, S., Neha, C., Deepti, K. (2015). An overview of hydro-electric power plant. ISST Journal of Mechanical Engineering, 6 (1), 59-62.

XM. (2015). Capacidad efectiva neta del SIN a diciembre 31 de 2014 Y 2015. Available from: http://informesanuales.xm.com.co/2015/ sitepages/operacion/2-6-Capacidad-efectivaneta.aspx

Chica, E., Agudelo, S., Sierra, N. (2013). Application of CFD to the design of the runner of a propeller turbine for small hydroelectric power plants. Revista facultad de ingeniería, 69. Available from: http://www.scielo.org.co/ scielo.php?script=sci_arttext\&pid=S012062302013000400015\&lang=es 